\section{Spectrum of neurosurgical complications following medical tourism: challenges of} patients without borders

Emmanuel Olufemi Idowu', Oladipo Adeboluji Adewole ${ }^{2}$

1. Lagos State University College of Medicine and Lagos State University Teaching Hospital, Ikeja, Lagos, Nigeria, Surgery (Neurosurgery Unit)

2. Lagos State University College of Medicine, Ikeja, Surgery (Orthopaedics)

\section{Abstract}

Background and objectives: The cost of medical care and availability of resources (human and facilities) which differs from nation to nation are amongst others, factors driving medical tourism (MT) despite its potential drawbacks. The aim of from nation to nation are amongst others, factors driving medical tourism (MT) despite its potential
the study was to analyse all patients that presented with neurosurgical complications following MT.

Methods: A single institution prospective study was carried out. Data which included patients' demographics, diagnosis, Glasgow coma scale score at admission, type of complication, and outcome were collected over a 3 year period and analysed.

Results: A total of 23 neurosurgical cases were seen during the study period with a median age of 42 years (17-70 years). India is the most common country visited by Nigerian patients. Nine patients died from various complications on arrival in Nigeria. There was no significant statistical difference between the outcome and patients clinical status prior to travel $(\mathrm{p}=0.107)$, country where the surgery was done $(\mathrm{p}=0.776)$, admission GCS in Nigeria $(\mathrm{p}=0.169)$, and redo surgery in Nigeria (0.181).

Conclusion: Government in different nations should have legislations to ensure that medical tourists' receive appropriate care abroad, proper follow-up care upon their return, and also promulgate laws to regulate quasi and organised MT agencies that are operating in a regulatory vacuum.

Keywords: Medical tourism, Morbidity, Mortality

DOI: http://dx.doi.org/10.4314/ahs.v15i1.31

Introduction
The price tag on medical care and availability of re-
sonnel, delay in surgical intervention,prohibitively sources (human and facilities) differs from nation to expensive medical care and offering of treatment that nation. These amongst others have been one of may be illegitimate in a patients home country, the dynamics driving medical tourism (MT) despite its potential drawback and perils.

In times past, hospital facilities in high-income councountry to access non-emergent medical care, often of other countries ${ }^{5,6}$; neurosurgical cases being among surgery ${ }^{1,2}$. It is generally portrayed as a potential solu- the common diseases. However, in recent times, hospition to a wide range of clinical conditions encumbering tals positioning themselves as leading medical tourism the health care systems in patients' home countries; a (MT) destinations are largely found within lower and middle income countries. In these hospitals, favourable exchange rates is presently giving them a competitive advantage especially among price-conscious international patients $s^{3,7}$. Governments and private organizations in these countries are also helping in promoting the MT industry ${ }^{8}$.

The concept of MT is a rapidly developing phenomenon with policy implication for health systems. Growth in the popularity of MT has resulted in an of increase attention being given to it from researchers, policy-makers, and the media. Irrespective of the precise growth rate, it is generally agreed that the MT industry is growing rapidly in many Asian and South American nations, and is poised for additional growth in countries with the necessary human and technical resources ${ }^{3,9}$ The industry is a highly profitable source of hard currency for host countries and a net loss of capital to departure countries. Arguably though, this is perhaps one of the most prominent factors driving medical tourism (MT) despite its potential drawback and perils.

Worthy of note is that MT can be extremely dangerous with fatal consequences to the medical tourist. As we know, even the slightest neurosurgical gaffe can be fatal. There are several draw back associated with medical tourism that are not usually well thought-out. Health care regulation standard varies from nation to nation and quite a number do not have rigorous checks and balances on what medical professionals need to do to get certified and to keep practicing. Secondly, patients may get drawn in by the possibility of a low cost procedure but end up paying far more as the patient is yet to be properly clerked and investigated; they may even be managed by inappropriate medical personnel or have unsuitable surgical procedures. Besides, the patient sacrifices his or her familiarity, loss of continuity of professional care and probably loose significant if not all legal guarantees by going for health care beyond their border; it will be quite demanding if not mission impossible to seek damages in case of negligence or incompetence. In addition, the spread of infectious diseases across national borders remains a probable risk. Given its positive and negative effects on the health care systems of departure and destination countries, medical tourism is a highly significant and contested phenomenon ${ }^{2}$.

Globally, there are limited data on clinical outcomes associated with MT especially in departure third world countries; and there is currently few data on the impact of MT on patients. In Nigeria, the MT industry is more or less quasi with various registered and unregistered agencies, and persons assisting patients to access non-emergent and even emergent medical care abroad. This has since taken a quantum leap in re- cent years in the country. A lack of reliable data about MT makes it difficult to create health system policy, and public health responses to address the associated risks and shortcomings, such as spread of infectious diseases, amongst others, associated with this industry. Yet, there has been little effort to systematically synthesize what is known about the effects of this phenomenon. The aim of our study is to analyse all patients that presented with neurosurgical complications following MT.

The series consisted of a prospective study of all patients that presented at our centre after having surgery at an outside facility outside our national boundary. The data was collected over a 3 year period, January 2011 to December 2013

A detailed clinical history and physical examination was done in all the cases. Cranial and or spinal computed tomographic scan with a cranial/spinal magnetic resonance imaging was done in all the index patients with additional investigations as required. The data documented included patients demographics, clinical status prior to travel for surgery abroad (emergent or non-emergent), diagnosis (prior to travelling and on presenting to us), region of the body involved (Cranial or spinal), country where procedure was done, medical report from MT centre, Glasgow coma scale GCS) score on admission, and outcome (dead or alive). Complications were characterized as lethal (mortality), causing new permanent deficits (permanent morbidity), causing new transient deficits (transient morbidity). Analysis of the variables was by simple proportion and percentages. Fischer's exact test was used to determine the differences between group means. A probability (p) of less than 0.05 was considered statistically significant.

Results:

A total of 23 neurosurgical cases were seen during the study period. Of these cases, 13 were males. The median age was 42 years (17-70 years). The indication for MT was due to intracranial lesions in 10 patients ( 7 males, 3 females) and spinal diseases in 13 individuals $(6$ males, 7 females). The most visited country was India (17 cases, $73.9 \%$ ) (Figure 1). 
Figure 1. Countries visited by the patients for medical tourism

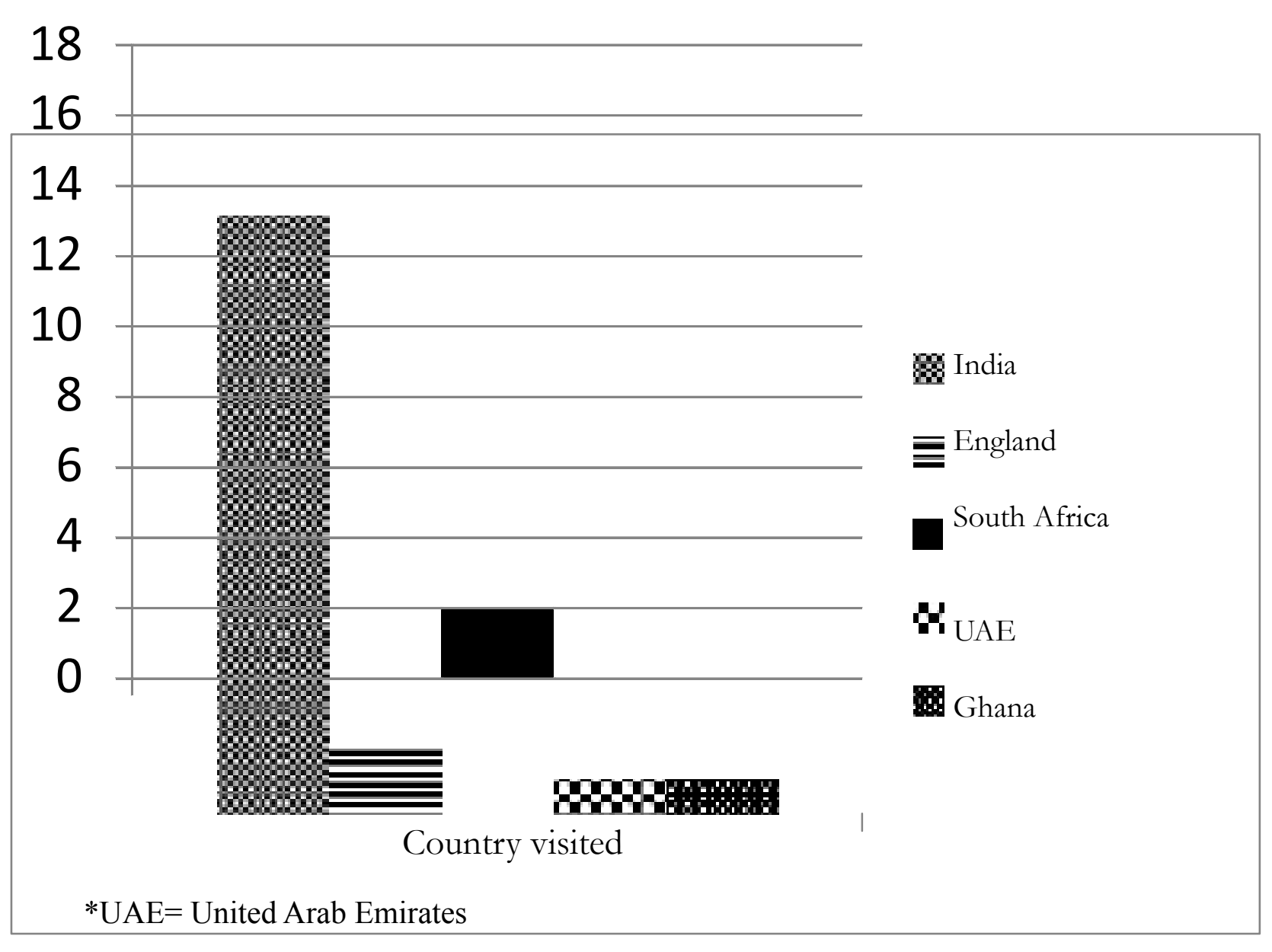

All the patients travelled by air lasting at least 6 hours, issues like complete cervical spine injury. The clinical except one patient that travelled by road to Ghana ( 7 status of the patient was emergent in 8 of the $23 \mathrm{pa}-$ hours journey). All the patients that travelled by air used tients. The GCS was 15 in 18 patients (78\%) when they commercial airlines even for that had emergent clinical presented to us (Table 1).
Table 1: Summary of all patients

\begin{tabular}{|c|c|c|c|c|c|c|c|c|}
\hline Nos & Sex & $\begin{array}{l}\begin{array}{l}\mathrm{Age} \\
\text { (years) }\end{array} \\
\end{array}$ & Diagnosis & \begin{tabular}{|l|} 
MT \\
Country
\end{tabular} & \begin{tabular}{|l|}
$\begin{array}{l}\text { Pre-travelling } \\
\text { status }\end{array}$ \\
\end{tabular} & $\begin{array}{l}\text { GCS on } \\
\text { presenting }\end{array}$ & Complication & Outcome \\
\hline- & \begin{tabular}{|l|l|} 
Female \\
\end{tabular} & 68 & $\begin{array}{l}\text { Cervical/Lumbar } \\
\text { canal stenosis }\end{array}$ & India & Nonemergent & 15 & $\begin{array}{l}\text { Septicaemia from } \\
\text { retained gauze }\end{array}$ & Died \\
\hline 2 & \begin{tabular}{|l|l|} 
Female \\
\end{tabular} & 24 & $\begin{array}{l}\text { Traumatic } \\
\text { Incomplete Cervical } \\
6 \text { myelopathy }\end{array}$ & India & \begin{tabular}{|l|l|} 
Emergent \\
\end{tabular} & 7 & 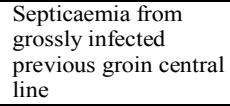 & Died \\
\hline 3 & Female & 42 & 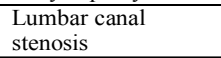 & \begin{tabular}{|l|l|} 
South \\
Africa
\end{tabular} & \begin{tabular}{|l|} 
Nonemergent \\
\end{tabular} & 15 & $\begin{array}{l}\text { Depp surgical site } \\
\text { intection }\end{array}$ & TM \\
\hline 4 & Female & 54 & $\begin{array}{l}\text { Traumatic } \\
\text { Incomplete Cervical } \\
6 \text { myelopathy }\end{array}$ & India & Emergent & 15 & $\begin{array}{l}\text { Deep surgical site } \\
\text { infection }\end{array}$ & TM \\
\hline 5 & Male & 51 & $\begin{array}{l}\text { CervicallLumbar } \\
\text { canal stenosis }\end{array}$ & India & Nonemergent & 15 & Wrong level surgery & TM \\
\hline 6 & Female & 70 & $\begin{array}{l}\text { Cervicall/Lumbar } \\
\text { canal stenosis }\end{array}$ & India & Nonemergent & 15 & $\begin{array}{l}\text { Wrong level//w } \\
\text { chair bound }\end{array}$ & PM \\
\hline 7 & Male & 30 & $\begin{array}{l}\text { Traumatic Complete } \\
\text { Cervicap } 5 \\
\text { myeloathy }\end{array}$ & \begin{tabular}{|l} 
South \\
Africa
\end{tabular} & Emergent & 8 & Ventilator dependent & Died \\
\hline 8 & Female & 17 & $\begin{array}{l}\text { Traumatic } \\
\text { Incomplete Cervical } \\
5 \text { myelopathy }\end{array}$ & India & Emergent & 15 & $\begin{array}{l}\text { Non-reduction of } \\
\text { subluxation }\end{array}$ & TM \\
\hline 9 & Female & 38 & $\begin{array}{l}\text { Thoracic aneurysmal } \\
\text { bone cyst }\end{array}$ & India & Nonemergent & 15 & Biopsy done & PM \\
\hline 10 & Male & 54 & $\begin{array}{l}\text { Lumbar canal } \\
\text { stenosis }\end{array}$ & UAE & Nonemergent & 15 & $\begin{array}{l}\text { Deep surgical site } \\
\text { infection }\end{array}$ & TM \\
\hline 11 & Male & 19 & $\begin{array}{l}\text { Traumatic Complete } \\
\text { Cervical } 5 \\
\text { myelopathy }\end{array}$ & India & Emergent & 15 & Stem cell failure & TM \\
\hline 12 & Male & 48 & $\begin{array}{l}\text { Conus medullaris } \\
\text { tumour }\end{array}$ & Ghana & \begin{tabular}{|l|} 
Nonemergent \\
\end{tabular} & 15 & Pulmonary embolism & Died \\
\hline 13 & Male & 41 & $\begin{array}{l}\text { Traumatic Complete } \\
\text { Cervical } 5 \\
\text { myelopathy }\end{array}$ & India & Emergent & 8 & Pulmonary embolism & Died \\
\hline 14 & Female & 32 & $\begin{array}{l}\text { Letten intraventricular } \\
\text { meningioman }\end{array}$ & India & Nonemergent & 15 & Seizures & TM \\
\hline 15 & Male & 45 & $\begin{array}{l}\text { Sphenoid ridge } \\
\text { meningioma }\end{array}$ & India & \begin{tabular}{|l} 
Nonemergent \\
\end{tabular} & 15 & $\begin{array}{l}\begin{array}{l}\text { Subtotal lese } \\
\text { with mass }\end{array} \\
\end{array}$ & TM \\
\hline 16 & Male & 18 & 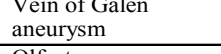 & India & Nonemergent & 15 & $\begin{array}{l}\text { Inadequate } \\
\text { embolization }\end{array}$ & $\mathrm{TM}$ \\
\hline 17 & Male & 65 & $\begin{array}{l}\text { Olfactory groove } \\
\text { meningioma }\end{array}$ & India & Nonemergent & 8 & $\begin{array}{l}\text { Incomplete surgery } \\
\text { due to li }\end{array}$ & $\mathrm{PM}$ \\
\hline$\frac{18}{19}$ & \begin{tabular}{|l|} 
Male \\
Female
\end{tabular} & $\frac{70}{22}$ & $\begin{array}{l}\text { Nonftintional } \\
\text { Pitutary adenoma } \\
\text { Acromegaly }\end{array}$ & \begin{tabular}{|l} 
India \\
England
\end{tabular} & \begin{tabular}{|l} 
Nonemergent \\
Nonemergengnt
\end{tabular} & $\frac{15}{15}$ & $\begin{array}{l}\text { Pulmonary emboliss } \\
\text { Inadequate surgegry }\end{array}$ & $\frac{\text { Died }}{\text { TMM }}$ \\
\hline 20 & Male & 28 & 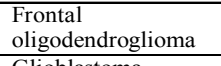 & India & \begin{tabular}{|l|} 
Nonemergent \\
\end{tabular} & 15 & Seizures & TM \\
\hline 21 & Male & 65 & $\begin{array}{l}\begin{array}{l}\text { llioblastoma } \\
\text { multiformes }\end{array} \\
\text { mate }\end{array}$ & India & Emergent & 15 & Status epilepticus & Died \\
\hline 22 & Male & 42 & $\begin{array}{l}\text { Olfactory groove } \\
\text { meningioma }\end{array}$ & England & \begin{tabular}{|l} 
Nonemergent \\
\end{tabular} & 14 & $\begin{array}{l}\text { CSF } \\
\text { leak/seizure/death }\end{array}$ & Died \\
\hline 23 & Female & 18 & $\begin{array}{l}\text { Postreriof fossa } \\
\text { medulloblastoma }\end{array}$ & India & Emergent & 15 & $\begin{array}{l}\text { Ventriciuloper } \\
\text { shunt sepsis }\end{array}$ & Died \\
\hline
\end{tabular}

"GCS- Glasgow coma score, PM- Permanent new morbidity, TM- Temporary new morbidity

Two patients had wrong level surgery and the most There was no significant statistical difference between common complication was infection (6 patients, $26 \%$ ). the outcome and gender, region of lesion, patients clinNine patients died from their complication after re-pre- ical status prior to travel (need emergent or nonemersenting in Nigeria (Table 2), a third of which was ac- gent intervention) (Table 2), country where the surcounted for by septicaemia. gery was done $(\mathrm{p}=0.776)$, admission GCS in Nigeria $(\mathrm{p}=0.169)$, and redo surgery $(\mathrm{p}=0.181)$.

Table 2. Outcome of patients related to gender, region of surgery and pre-operative clinical status of patients

Died Permanent deficit Transient deficit p-value

\begin{tabular}{lcccc} 
& Died & Permanent deficit & Transient deficit & p-value \\
\hline Gender & & & & \\
$\quad$ Male & 6 & 1 & 6 & \\
$\quad$ Female & 3 & 2 & 5 & 0.589 \\
Pre-operative status & & & & \\
$\quad$ Emergent & 5 & 0 & 3 & \\
$\quad$ Non-emergent & 4 & 3 & 8 & 0.107 \\
Location of lesion & & & & \\
$\quad$ Intracranial & 4 & 1 & 5 & 0.928 \\
Spinal & 5 & 2 & 6 & \\
\hline
\end{tabular}




\section{Discussion} 19th centuries, when people travelled to spas to "take which she died from. None of this patient could have the waters" as a means of improving their health; like- a legal redress. In the literature there is no substantia wise people in remote settlements and less developed proof to suggest negligent issues amongst MT brocountries, have always travelled to reach clinics or physi- kerages. Despite this, the obvious regulatory vacuum cians for aid $^{10,11}$. However in the last two decades, there around MT services leaves room for hazardous medical have been an extensive denationalization and marketi- and business practices; hence the need to proactively zation of health care globally (developing and in devel- manage MT. At present MT should be viewed as an oped countries) $)^{9}$.

The fact that people are able and willing to travel long distances, even to developing nations, for cheaper-cos health care suggests that health care in the developed countries has become too expensive or too inaccessible for many people ${ }^{10-12}$. Third world countries commonly visited by patients for health care include India, Malaysia, Singapore, and Thailand. In Nigeria, India is the leading country that patients travel to for medical procedures. Almost three-quarters of our patients in this study had visited India.

Medical tourists are at risk for hospital infection, acquired and nosocomial ${ }^{13}$. These pathogens which they may import to their country may be rare and it may even be a multidrug resistant strain. The most common reason for presenting to our facility was infection $(26 \%)$. A third of the 9 patients that died had septicaemia.

In study from the United Kingdom (UK), it was noted that the UK is a clear net exporter of medical travellers. In 2010, an estimated 63,000 UK residents travelled for treatment, while around 52,000 patients sought treatment in the UK ${ }^{14}$. However in Nigeria, there is no reliable data on patient numbers, flows, treatment types and success rates. Success rates are generally reported by some patients, relations, news media and quasi agencies without an independent auditor or the inclusion of long-term success rates after medical tourists return to their home countries. These success rates are at best notional. In addition, a lack of dependable data about MT makes it difficult to create policy to improve patient safety measures or guide the development of the industry in an equitable and ethical manner, to improve our local health system, and publicize public health responses to address the associated risks and shortcomings associated with this industry (e.g. spread of infectious diseases)

Despite the rapid expansion of the MT industry, fey dards exist to ensure that these businesses organ-

Nigeria, many quasi MT companies are now involved in organizing cross-border health services. Most of thes standards in the offered. There are no regulatory criteria intended to protect the health and financial interests of patients.

Although this study did not find any statistically significant association between patients' outcome and country visited for treatment. Nigeria and other developing countries have the obligation to implement public policies to moderate the demand for MT by thei populaces. A call for a comprehensive public health response to MT and its effects should be coupled with a clear understanding that medical tourism is a highly diverse practice.

There is need for research to produce dependable understandings about the scope and volume of the practice of MT in a way that is comparable across facilities and countries. This may also offer insights into imporant differences between medical tourists based on demographic factors, patients' health status, etc.

Since there is an increasing numbers of patients travelling in search of medical care beyond their national boundaries despite its associated risks, Government ministries in all nations from which patients depart fo ical tourists' receive appropriate care abroad, proper follow-up care upon their return, and promulgate aws to help in regulating most of the qua ganised MT agencies that are operating in a regulatory vacuum.
1. MacReady N: Developing countries court medical tourists. Lancet 2007; 369:1849-1850.

2. Hutson Gray H, Cartier Poland S: Medical Tourism: Crossing Borders to Access Health Care. Kennedy Inst Ethics J 2008; 18:193-201.

3. Pocock NS, Phua KH: Medical tourism and policy implications for health systems: a conceptual framework from a comparative study of Thailand, Singapore and Malaysia. Global Health 2011; 7:12.

4. Chen YY, Flood CM: Medical Tourism's Impact on Health Care Equity and Access in Low- and Middle-Income Countries: Making the Case for Regulation. J Law Med Ethics 2013; 41:286-300.

5. Whittaker A: Pleasure and pain: Medical travel in Asia. Glob Public Health 2008; 3:271

13. Chen LH, Wison ME: The globalization of What is known about the effects of J, Kingsbury P: healthcare: implications of medical tourism for the inin destination and departure countries? A scoping 1759 .

review. Int J Equity Health 2010; 9:24

spitals - First-World Health Care at Emeroin ket Prices Boston, Mass: Harvard Business School Cass; 2007

. Ehrbeck T, Guevara C, Mango PD, Cordina J, Singhal S: Health care and the consumer. McKinsey uarterly 2008; 4:80-81.

10. Connell J: Medical tourism: sea, sun, sand and . surgery. Tourism Manage. 2006; 27:1093-1100.

11. Smythe G: Medical geography: therapeutic places, personnel are not trained nor are they familia care abroad should have legislations to ensure that med7. Lautier M: Export of health services from develop- cal tourism: a cost or benefit to the NHS? PLoS One. ing countries: The case of Tunisia. Soc Sci Med 2008; 2013;8:e70406. doi: 10.1371/journal.pone.0070406. 67:101-110. 